\title{
Reports to the UK Yellow Card Scheme 2000- 2009 for medications used in paediatric rheumatology
}

Daniel B Hawcutt ${ }^{1,2^{*}}$, Clare Pain ${ }^{2}$, Rachel Mulholland ${ }^{2}$, Lisa M Cann², Gavin Cleary ${ }^{2}$, Michael W Beresford ${ }^{1,2}$, Eileen Baildam²

From 18th Pediatric Rheumatology European Society (PReS) Congress

Bruges, Belgium. 14-18 September 2011

\section{Background \& aims}

The Medicines and Healthcare Regulatory Authority (MHRA) in the UK runs a national spontaneous reporting system (Yellow Card Scheme) to collect 'suspected' Adverse Drug Reactions (ADRs) for all medicines. To increase the data for paediatric medicines, current MHRA advice is to report all suspected ADRs in paediatric patients. Yellow Cards submitted between 2000 and 2009 were analysed for medications commonly used in paediatric rheumatology.

\section{Methods}

Data on all UK spontaneous 'suspected' ADRs reported to the MHRA in patients $<17$ years from the years 2000 9 were supplied. Data included age, type of reaction, medication and type of reporter, but were unlinked. Data were only supplied on an individual drug if five or more suspected ADRs were reported in a calendar year. The cut-off values in the data supplied were in accordance with policy guidelines applied by the MHRA to preserve confidentiality of reporters and patients.

Table 1

\begin{tabular}{|c|c|c|c|c|c|c|c|c|c|c|c|}
\hline Drug & 2000 & 2001 & 2002 & 2003 & 2004 & 2005 & 2006 & 2007 & 2008 & 2009 & Total \\
\hline ALEMTUZUMAB & & & & & & & & 9 & & 22 & 31 \\
\hline AZATHIOPRINE & & & & & 6 & & & & 8 & & 14 \\
\hline CYCLOPHOSPHAMIDE & & & & & 11 & & & & 18 & 36 & 65 \\
\hline CYCLOSPORIN & 6 & & & 6 & & 6 & 9 & 9 & 25 & 59 & 120 \\
\hline ETANERCEPT & & & & 8 & 8 & 22 & 22 & 20 & 14 & & 94 \\
\hline ETOPOSIDE & & & & & & & & & 5 & 7 & 12 \\
\hline INFLIXIMAB & 5 & & 7 & & & 10 & 5 & 10 & 11 & 20 & 68 \\
\hline METHOTREXATE & 6 & & 5 & 9 & 8 & 16 & 11 & 13 & 39 & 40 & 147 \\
\hline MYCOPHENOLIC ACID & & & & & & & & & & 8 & 8 \\
\hline PREDNISOLONE & & & & & & 6 & & 12 & 14 & 19 & 51 \\
\hline RITUXIMAB & & & & & & & & & 7 & 5 & 12 \\
\hline TACROLIMUS & & & 8 & 12 & 7 & 10 & 13 & 12 & 7 & 18 & 87 \\
\hline
\end{tabular}

* Correspondence: d.hawcutt@liv.ac.uk

'University of Liverpool, UK

Full list of author information is available at the end of the article

C Biomed Central

C 2011 Hawcutt et al; licensee BioMed Central Ltd. This is an open access article distributed under the terms of the Creative Commons Attribution License (http://creativecommons.org/licenses/by/2.0), which permits unrestricted use, distribution, and reproduction in any medium, provided the original work is properly cited. 


\section{Results}

The number of reports of suspected ADRs to drugs commonly used in paediatric rheumatology per year are shown in Table 1. Adalimumab, tocilzumab \& abatacept did not generate sufficient reports to feature in the dataset. There has been an increase in reporting over the 10 year period, with a median of 17 (2000-2) increasing to a median of 148 (2007-9). This increase is greater than the overall increase in reporting seen in the period (Hawcutt et al, submitted). However, the unlinked nature of the data supplied means that it is not possible to ascertain if the medications were prescribed in paediatric rheumatology patients.

\section{Conclusions}

Medications commonly used in paediatric rheumatology generate suspected ADR reports in the UK. The overall reporting rate appears to be increasing, but reporting of biologics is lower than expected

\section{Author details}

${ }^{1}$ University of Liverpool, UK. ${ }^{2}$ Alder Hey Children's Hospital, Liverpool, UK.

Published: 14 September 2011

doi:10.1186/1546-0096-9-S1-P237

Cite this article as: Hawcutt et al:: Reports to the UK Yellow Card

Scheme 2000-2009 for medications used in paediatric rheumatology.

Pediatric Rheumatology 2011 9(Suppl 1):P237.
Submit your next manuscript to BioMed Central and take full advantage of:

- Convenient online submission

- Thorough peer review

- No space constraints or color figure charges

- Immediate publication on acceptance

- Inclusion in PubMed, CAS, Scopus and Google Scholar

- Research which is freely available for redistribution

Submit your manuscript at www.biomedcentral.com/submit
C Biomed Central 